\title{
М. М. Яременко,
}

к. е. н., Аоцент, Аоцент кафедри фінансів, обліку і оподаткування,

АВНЗ "Переяслав-Хмельницький державний педагогічний університет імені Григорія Сковороди", м. Переяслав-Хмельницький

ORCID ID: 0000-0003-3127-5181

DOI: $10.32702 / 2306-6792.2020 .2 .53$

\section{МЕХАНІЗМ ФОРМУВАННЯ ФОНАУ ОПЛАТИ ПРАЦІ ТА НАПРЯМИ ЙОГО УАОСКОНААЕННЯ}

\author{
L. Yaremenko, \\ $\mathrm{PhD}$ in Economics, Associate Professor SHEE "Pereyaslav-Khmelnytskiy SPU \\ after Grygoriy Skovoroda", Pereyaslav-Khmelnytskiy
}

\author{
THE MECHANISM FORMATION OF A PAYROLL FUND AND THE DIRECTIONS \\ OF ITS IMPROVEMENT
}

У статті досліджено теоретичні аспекти заробітної плати як соціально-економічної категорії, з одного боку, як Ажерело грошових доходів найманих працівників, а 3 іншого, як суттєва частина витрат підприємства. Висвітлено основні аспекти формування фонду оплати праці в розрізі трьох елементів основної заробітної плати, додаткової заробітної плати та інших компенсаційних та заохочувальних виплат з детальним їх групуванням. Проблему формування фонду оплати праці в Україні досліджували та продовжують досліджувати багато науковців, при цьому найбільша увага приділяється вивченню саме основної заробітної плати, проблему додаткової заробітної плати та інших заохочувальних та компенсаційних виплат персоналу вивчено недостатньо. Узагальнено основні нормативно-правові документи, за допомогою яких здійснюється державне регулювання оплати праці в Україні. Аоведено, структура заробітної плати є організаційно-правовим механізмом, який відАзеркалює становище виплат, що передбачені трудовим договором та чинним законодавством Аля працівника. Запропоновано основні напрями удосконалення класифікації виплат у розрізі додаткової заробітної плати та інших заохочувальних та компенсаційних виплат, які мають бути націлені на соціально-економічний характер та на вимоги часу, що має стати запорукою сталого соціально-економічного розвитку країни.

The article examines the theoretical aspects of wages as a socio-economic category - as a source of cash income of employees on the one hand, and as a significant part of the costs of the enterprise on the other. It is determined that wages are workers' cash income, which depends on the amount of labor spent during the creation of a tangible good or a specific product, or the time spent in providing a service. The main aspects of the formation of the payroll fund in the context of three elements of basic wages, additional wages and other compensation and incentive payments with their detailed grouping are studied. The problem of forming a wage fund in Ukraine has been researched and continues to be researched by many scholars, with the greatest attention being paid to the study of basic wages. The problem of additional wages and other incentive and compensatory payments to staff has not been sufficiently studied. The basic normative legal documents, which regulate the state labor remuneration in Ukraine, are summarized. It has been determined that the Code of Laws of Labor of Ukraine, which regulates the right of every employee to receive a salary, acts as a codified normative legal act on the legal regulation of wages. It is proved that the structure of wages is an organizational and legal mechanism that reflects the situation of payments stipulated by the employment contract and the legislation in force for the employee. The mechanism of the organization of remuneration is based on the structure of wages, which is influenced by the state of economic and political situation in the country. The basic directions of improvement of the classification of payments in terms of additional wages and other incentive and compensatory payments are proposed. They should be 
focused on socio-economic nature and time requirements, as well as introduction of new types of payments according to the time requirements, which would express productivity and efficiency of work in order to motivate the highly skilled workers and based on individual results of an individual worker. This should be the key to sustainable socio-economic development of the country.

Ключові слова: фонд оплати прачі, основна заробітна плата, додаткова заробітна плата, інші заохочувальні та компенсачійні виплати, структура заробітної плати.

Keywords: payroll fund, base wages, additional wages, other incentive and compensation payments, wage structure.

\section{ПОСТАНОВКА ПРОБЛЕМИ}

Сучасні економічні та трансформаційні зміни, які відбуваються в Україні мають передусім бути здійснені в інтересах людини і направлені на поліпшення якості їі життя. Основною проблемою сьогодення $є$ проблема заробітної плати, та організації її ефективності. Під заробітною платою ми розуміємо грошовий дохід працівників, що залежить від кількості витраченої праці під час створення матеріального блага або конкретного товару, або витрат робочого часу у разі надання послуги [8, с. 190]

Заробітна плата, характеризуючи рівень економічного та соціального стану суспільства з одного боку, є основним джерелом грошових доходів найманих працівників, а 3 іншого суттєвою частиною витрат підприємства. За сучасних умов заробітна плата $€$ найефективнішим засобом заохочення працівників до високої продуктивності праці, виступає як оплата послуг за виконану роботу та відображає соціально-економічне становище в національній економіці України та рівень життя в суспільстві. В Україні розмір заробітної плати є економічно необгрунтованим, а постійні зміни у нормативно-правовому законодавстві та недосконалість трудових відносин зумовлює соціально-економічну напруженість у суспільстві.

Зважаючи на вищевикладене, Україна потребує радикальних змін у системі організації й стимулюванні ефективності праці, ії оподаткуванні з метою оптимізації диференціації доходів всіх працівників. У цьому аспекті, доцільно розглянути структуру фонду оплати праці, яка визначена чинним законодавством і на основі якої формується інформація про оплату праці окремого підприємства. Запропонований чинним законодавством ще у далекому 2004 році перелік основних видів виплат (згідно з Інструкцією зі статистики заробітної плати), які є характерними для основної заро- бітної плати, додаткової заробітної плати та інших заохочувальних та компенсаційних виплат не передбачає детального групування та потребує удосконалення відповідно до вимог часу.

На сьогодні питання щодо наявності достатньої кількості аналітичних даних щодо складових фонду оплати праці кожного працівника, структури заробітної плати та ï особливостей, що забезпечується лише за рахунок оптимально організованої системи бухгалтерського обліку залишається дискусійним питанням та набуває все більшої актуальності.

\section{АНАЛІЗ ОСТАННІХ ДОСЛІДЖЕНЬ І ПУБЛІКАЦІЙ}

Теоретичні, методичні і прикладні питання різносторонньої проблеми обліку праці, їі оплати та розрахунків з персоналом в розрізі основної, додаткової заробітної плати та інших заохочувальних та компенсаційних виплат завжди залишалися предметом наукових досліджень: П.Й. Атамаса, Ф.Ф. Бутинця, С.Ф. Голова, М.В. Кужельного, В.В. Сопка, В.Г. Швеця, М.М. Яременко та інших.

Серед зарубіжних публікацій щодо дослідження мотиваційного механізму, а також взаємозв'язку винагороди працівників з ефективністю праці, відзначаються класичні роботи Ф. Герцберга, А. Маршалла, А. Маслоу, А. Piкардо, П. Самуельсона, Ф. Тейлора, А. Сміта, Ж. Сей, Аж. Кейнса, У. Ажевонса, А. Аубліна, К. Маркса, К. Менгера, В. Петті, А. Рікардо та багато інших.

\section{ВИДІЛЕННЯ НЕ ВИРІШЕНИХ РАНІШЕ ЧАСТИН ЗАГАЛЬНОЇ ПРОБЛЕМИ}

Напрацювання вітчизняних науковців протягом останніх років спрямовані на вдосконалення лише одного елемента структури заро- 
бітної плати, а саме - основної заробітної плати. Аіючу практику додаткової заробітної плати та інших заохочувальних та компенсаційних виплат персоналу, на нашу думку, висвітлено недостатньо, що і зумовило необхідність подальших досліджень зазначеної проблематики.

\section{META CTATTI}

Метою статті є обгрунтування структури фонду оплати праці, нормативно-правових засад за допомогою яких здійснюється державне регулювання фонду оплати праці в Україні та запропонування напрямів щодо удосконалення класифікації виплат у розрізі фонду оплати праці враховуючи вимоги сьогодення.

\section{ВИКЛАДЕННЯ ОСНОВНОГО МАТЕРІАЛУ}

Складовими поточних виплат працівникам є: заробітна плата за окладами й тарифами, інші нарахування з оплати праці; виплата за невідпрацьований час (щорічні відпустки та інший оплачуваний невідпрацьований час); премії та інші заохочувальні виплати, що підлягають сплаті впродовж дванадцяти місяців після закінчення періоду, у якому працівники виконують, відповідну роботу тощо. Основним джерелом доходів найманих працівників була і залишається протягом останніх років - заробітна плата.

В основі механізму організації оплати праці лежить структура заробітної плати, яка $є$ внутрішньою побудовою заробітної плати та формується із впорядкованих певним чином та пов'язаних між собою елементів основної заробітної плати, елементів додаткової заробітної плати та елементів інших компенсаційних та заохочувальних виплат. Такий поділ заробітної плати на основну, додаткову, інші компенсаційні та заохочувальні виплати є специфічним, адже кожен із цих зазначених елементів має власні, передбачені чинним законодавством сукупні виплати. Чіткість визначення складових структури заробітної плати для забезпечення надійності та стабільності отримання усіх виплат має надзвичайно актуальне значення на сьогодні, що мало б призвести до досягнення вищого рівня матеріального забезпечення кожного працівника та сприяти економічному розвитку держави в цілому. Особливість вітчизняної структури заробітної плати полягає в тому, що вона відображає усі реальні виплати, які працівник може отримати в процесі трудової діяльності загалом, та виконання службових обов'язків зокрема.
Формування фонду оплати праці здійснюється на кожному підприємстві, до уваги береться кількість працівників, які беруть пряму участь у виробничому процесі, рівень їхньої кваліфікації, повноваження, рівень оплати праці та ін. Склад фонду оплати праці штатних працівників відображається у розділі III "Склад фонду оплати праці штатних працівників" Звіту з праці за кожний квартал окремо, де враховуються вимоги законодавства, розмір мінімальної заробітної плати, оплата відпусток, понадурочних годин, робота в нічний час, святкові та неробочі дні, виплата допомоги 3 тимчасової непрацездатності та ін. Фонд оплати праці на підприємстві напряму залежить від обсягів реалізованої продукції та від рівня продуктивності праці.

Нормативно-правове регулювання щодо питання структури заробітної плати здійснюється на основі Конституції України [3], Кодексу законів про працю України [2], Закону України "Про оплату праці" [7], а також низки підзаконних нормативно-правових актів, серед яких Постанова КМУ "Про упорядкування структури та умов оплати праці працівників апарату органів виконавчої влади, органів прокуратури, судів та інших органів" № 268 від 09.03.2006 р. [6], наказ АКСУ "Про затвердження Інструкції зі статистики заробітної плати" № 5 від 13.01.2004 р. [1].

Кодекс законів про працю України не розкриває власне сутність поняття "структура заробітної плати". Тому ми вважаємо, що сутність поняття "структура заробітної плати" має обов'язково знайти своє відображення у Кодексі законів про працю України. На фоні цього привертає увагу Податковий кодекс України, який дублює норми, які зазначені у Законі України "Про оплату праці" [2]. Так, відповідно до Податкового кодексу УКраїни заробітна плата містить у собі основну, додаткову, заохочувальні та компенсаційні виплати за виконання трудових обов'язків під час реалізації відносин трудового найму, які виплачуються платнику податків у порядку, встановленому законодавством [5]. Водночас структуру заробітної плати регулює Закон України "Про оплату праці" [7], який дублює визначення заробітної плати, що зазначене в Кодексі законів про працю України [2], а саме формулює заробітну плату як винагороду, що обчислюється, як правило, у формі грошей, яка відповідно до закону виплачується працівникові за трудовим договором іншою стороною трудових відносин, а саме роботодавцем за виконання трудових 
Таблиця 1. Нормативно-правові засади управління фондом оплати праці

\begin{tabular}{|c|c|}
\hline $\begin{array}{c}\text { Нормативно- } \\
\text { правовий документ }\end{array}$ & Визнання щодо оплати праці \\
\hline $\begin{array}{l}\text { Закон України } \\
\text { «ро оплату } \\
\text { праці» [7] }\end{array}$ & $\begin{array}{l}\text { Визначає економічні, правові та організаційні засади оплати праці } \\
\text { працівників, які перебувають у трудових відносинах, на підставі } \\
\text { трудового договору з підприємствами, установами, організаціями усіх } \\
\text { форм власності та господарювання (далі - підприємства), а також } 3 \\
\text { окремими громадянами та сфери державного і договірного } \\
\text { регулювання оплати праці і спрямований на забезпечення } \\
\text { відтворювальної і стимулюючої функцій заробітної плати } \\
\end{array}$ \\
\hline $\begin{array}{l}\text { Інструкція зі } \\
\text { статистики } \\
\text { заробітної плати } \\
\text { [1] }\end{array}$ & $\begin{array}{l}\text { Розроблена відповідно до Законів України "Про } \\
\text { державну статистику" та "Про оплату праці" з урахуванням } \\
\text { міжнародних рекомендацій у системі статистики оплати праці й } \\
\text { стандартів Системи національних рахунків. Інструкція містить основні } \\
\text { методологічні положення щодо визначення показників оплати праці у } \\
\text { формах державних статистичних спостережень з метою одержання } \\
\text { об'єктивної статистичної інформації про розміри та структуру } \\
\text { заробітної плати найманих працівників }\end{array}$ \\
\hline $\begin{array}{l}\text { Кодекс законів про } \\
\text { працю [2] }\end{array}$ & $\begin{array}{l}\text { Визначає загальні правила регулювання індивідуальних трудових } \\
\text { відносин, умови праці, особливості регулювання окремих категорій } \\
\text { працівників, норми праці, трудову дисципліну, безпеку та охорону } \\
\text { праці, правила регулювання колективних трудових відносин }\end{array}$ \\
\hline $\begin{array}{l}\text { Закон «Про } \\
\text { бухгалтерський } \\
\text { облік та фінансову } \\
\text { звітність в } \\
\text { Україні» }\end{array}$ & $\begin{array}{l}\text { Визначає основні принципи бухгалтерського обліку та фінансової } \\
\text { звітності, державне регулювання бухгалтерського обліку та фінансової } \\
\text { звітності, порядок оформлення первинних документів та регістрів } \\
\text { бухгалтерського обліку, обов'язки підприємств під час складання } \\
\text { фінансової звітності, зокрема що стосуєтьсяоплати праці }\end{array}$ \\
\hline $\begin{array}{l}\text { Податковий кодекс } \\
\text { України [5] }\end{array}$ & $\begin{array}{l}\text { Визначає платників податку, дохід у зв’язку з роботою найманих } \\
\text { працівників та розмір утримання податку з доходів фізичних осіб із } \\
\text { заробітної плати працівника }\end{array}$ \\
\hline $\begin{array}{l}\text { Конституція } \\
\text { України [3] }\end{array}$ & $\begin{array}{l}\text { Гарантує кожному громадянину право на заробітну плату, не нижчу від } \\
\text { визначеної законом }\end{array}$ \\
\hline
\end{tabular}

обов'язків. У Законі України "Про оплату праці" також перераховано низку факторів, залежно від яких встановлюється розмір заробітнӧ̈ плати. Такими факторами є: складність виконаної роботи, професійні якості працівника, умови виконаної роботи, результати діяльності підприємства, результати діяльності працівника та ін. [7]. 3аконодавче визначення структури заробітної плати розкривається у ст. 2 Закону України "Про оплату праці" [7] та Інструкції зі статистики заробітнӧ̈ плати № 5 від 13.01.2004 р., які до структури заробітної плати відносять три особливі елементи: основну, додаткову заробітну плату та інші компенсаційні і заохочувальні виплати. Кожний із зазначених елементів регламентується законом [1].

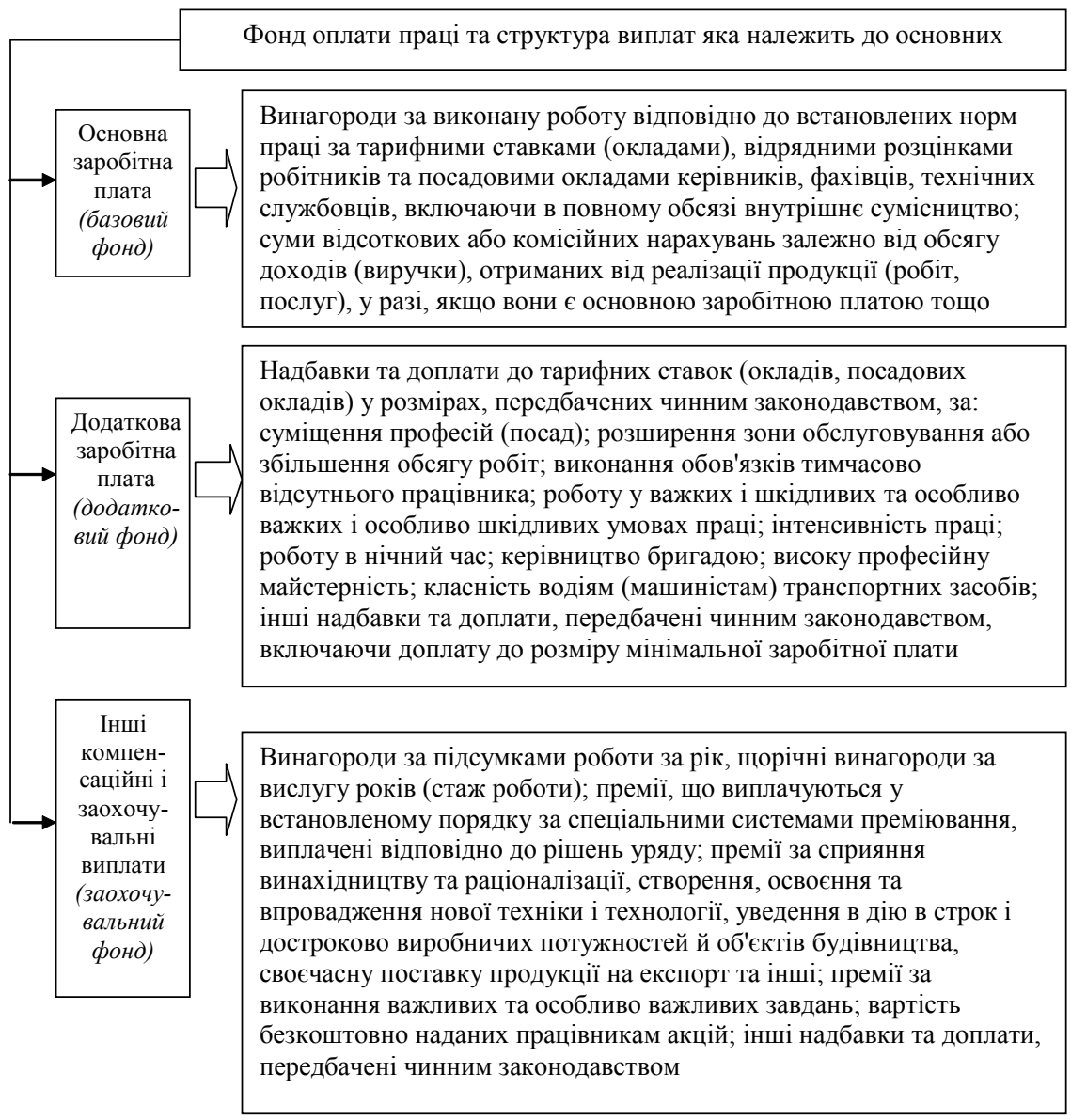

Рис.1. Складові фонду оплати праці 
Таблиця 2. Класифікація доплат до заробітної плати

\begin{tabular}{|c|c|}
\hline Група доплат & Перелік можливих доплат \\
\hline $\begin{array}{l}\text { Доплати, що мають водночас } \\
\text { стимулюючий і компенсуючий } \\
\text { характер }\end{array}$ & $\begin{array}{l}\text { - За суміщення професій (посад); } \\
\text { • за розширення зони обслуговування або } \\
\text { збільшення обсягу виконуваних робіт; } \\
\text { • на період освоєння нових норм трудових } \\
\text { витрат; } \\
\text { • бригадирам з робітників, яких не звільнено } \\
\text { від основної роботи; } \\
\text { • за ведення діловодства та бухгалтерського } \\
\text { обліку; } \\
\text { • за обслуговування обчислювальної техніки }\end{array}$ \\
\hline $\begin{array}{l}\text { Доплати компенсаційного } \\
\text { характеру за умови праці, що } \\
\text { відхиляються від нормальних }\end{array}$ & $\begin{array}{l}\text { - За роботу у важких, шкідливих та особливо } \\
\text { важких і шкідливих умовах; } \\
\text { • за інтенсивність праці; } \\
\text { • за роботу в нічний час; } \\
\text { • за перевезення небезпечних вантажів }\end{array}$ \\
\hline $\begin{array}{l}\text { Доплати, пов'язані з } \\
\text { особливим характером } \\
\text { виконуваних робіт - сезонністю, } \\
\text { віддаленістю, невизначеністю } \\
\text { об'єкта праці }\end{array}$ & $\begin{array}{l}\text { - За роботу у вихідні дні, що є робочими } \\
\text { за графіком; } \\
\text { • за багатозмінний режим роботи; } \\
\text { • водіям, які працюють на автомобілях, за } \\
\text { ненормований робочий день і роз’їзний } \\
\text { характер праці }\end{array}$ \\
\hline
\end{tabular}

Нормативно-правові засади, які визначають сутність управління фондом оплати праці, наведено в таблиці 1.

Кодифікованим нормативно-правовим актом щодо правового регулювання заробітної плати виступає Кодекс законів про працю України, який регламентує право кожного працюючого на отримання заробітної плати та розкриває сутність заробітної плати та її структури. Структура заробітної плати відображає їі внутрішню побудову та $є$ сукупністю певних складників у єдиному цілому. На структуру заробітної плати впливає багато чинників - стан економіки та політично-правова ситуація у країні. За таких обставин структура заробітної плати $є$ організаційно-правовим механізмом, який віддзеркалює стан виплат, що передбачені трудовим договором та чинним законодавством для працівника.

Міністерство статистики України у 2004 році затвердило Інструкцію зі статистики заробітної плати, яка затверджена Наказом Аержкомстату України від 13.01.2004, № 5 [1], в якій прописано повний перелік виплат, які входять до складу фонду оплати праці. Однак недостатність аналітичної інформації та відсутність більш детального групування виплат окремого структурного елемента негативно впливає на специфіку діяльності підприємства та не задовольняє потреби системи управління підприємства.

Такий поділ заробітної плати на основну, додаткову, інші компенсаційні та заохочувальні виплати є специфічним, адже кожен із цих зазначених елементів містить власні, передбачені чинним законодавством сукупні виплати. Особ- ливістю вітчизняної структури заробітної плати є відображення усіх реальних виплат, які працівник зможе отримати в процесі своєї трудової діяльності та при виконанні службових обов'язків.

Складові фонду оплати праці відображені на рис. 1.

Основна заробітна плата є базовим фондом на підприємстві та формується під впливом об'єктивних умов виробництва і праці та $€$ нагородою за працю, встановленою у вигляді тарифних окладів та відрядних розцінок, що згідно із встановленими нормами праці, зокрема посадовими обов'язками, виробітком, часом роботи, обслуговування та виплачується працівникові відповідно до кваліфікації, складності роботи, відповідальності, умов праці, інтенсивності.

Аодаткова заробітна плата - це винагорода за працю понад установлені норми, за трудові успіхи, винахідливість та за особливі умови праці (доплати, надбавки, гарантійні й компенсаційні виплати) та залежить від чинників виробничої діяльності працівників, які неможливо повністю врахувати заздалегідь і які відбивають специфічні умови праці на цьому підприємстві або особливості працівників.

По-перше, додаткова заробітна плата враховує індивідуальні результати тих працівників, які завдяки особистим здібностям досягли особливих успіхів. По-друге, додаткова заробітна плата враховує колективні результати праці. Переважно виплачується у вигляді премій та інших видів винагород з фонду матеріального заохочення. Премія - це не звичайна надбавка до заробітної плати, а особлива 
форма винагороди за творчі успіхи в роботі, за виконання завдань особливого значення [4]. На формування елементів складу додаткової заробітної плати впливають індивідуальні особливості трудової діяльності кожного працівника та його творчі здібності. Такі виплати $є$ характерними для тих підприємств, в яких є додатковий фонд оплати праці.

Інші заохочувальні та компенсаційні виплати формують заохочувальний фонд оплати праці на підприємстві - до них належать виплати у формі винагород за підсумками роботи за рік, премії за спеціальними системами і положеннями, компенсаційні та інші грошові і матеріальні виплати, які не передбачені актами чинного законодавства або які провадяться понад встановлені зазначеними актами норми. Аля забезпечення правильного використання фонду оплати праці необхідно обліковувати виробіток продукції або виконаний обсяг робіт кожним працівником і правильність нарахування заробітної плати згідно із встановленими нормами і розцінками. Основна відмінність цих виплат від двох інших складових фонду оплати праці полягає у тому, що до них належать винагороди та премії, які мають одноразовий характер, компенсаційні та інші грошові й матеріальні виплати, які не передбачені актами чинного законодавства або які провадяться понад встановлені зазначеними актами норми тощо. Ао інших заохочувальних та компенсаційних виплат також можуть відноситись виплати індивідуального характеру (наприклад, оплата квартири та найманого житла, гуртожитків, товарів, продуктових замовлень, абонементи у спортзал, передплати на газети та журнали, протезування, суми компенсації вартості виданого працівникам палива у випадках, не передбачених чинним законодавством).

Класифікацію доплат до заробітної плати, що здійснюються лише в певних (окремих) сферах прикладання праці, наведено в таблиці 2.

Фонд оплати праці та особливості його формування залишаються основним показником у сфері заробітної плати як на рівні держави, так і на рівні підприємства. На рівні держави фонд оплати праці виступає як частка національного доходу, яка розподіляється серед працюючого населення у формі заробітної плати. На рівні підприємства цей показник є загальною сумою заробітної плати, нарахованої працівникам за виконану роботу, а також оплати невідпрацьованого часу у відповідності з трудовим законодавством та колективним договором, який підлягає оплаті, незалежно від джерел фінансування цих витрат

На рівень оплати праці впливає ряд об'єктивних і суб'єктивних факторів: коливання попиту і пропозиції на ринку праці, рівень безробіття, стан економіки, продуктивність праці, державне регулювання, складність і умови праці, кваліфікація тощо. Одним із головних факторів,

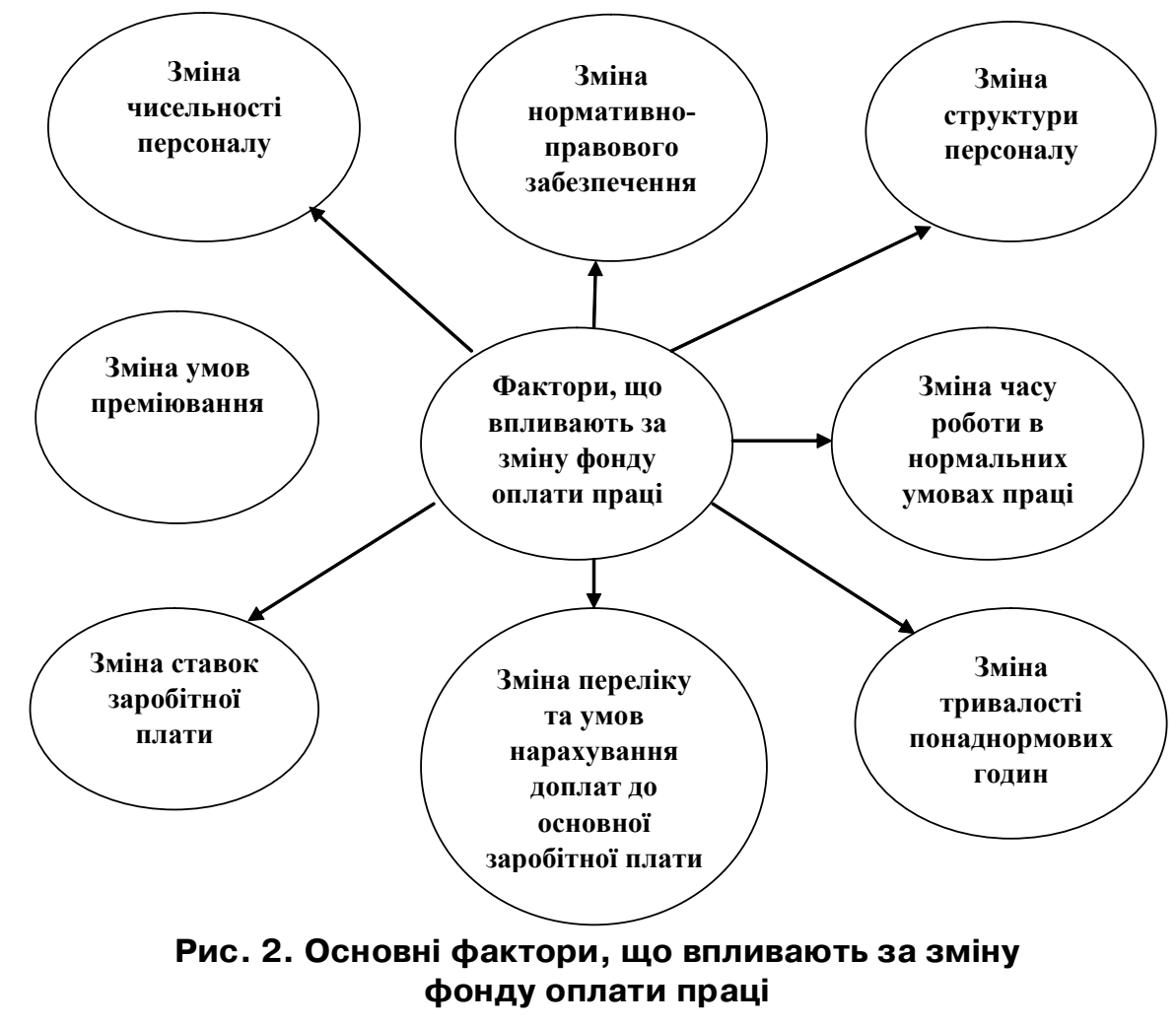


який впливає на рівень, оплати праціє стан економіки в Україні, який є нестабільним на сьогодні через кризу, що прогресує в нашій державі.

Аля подолання багатьох соціальних проблем, які існують в Україні необхідно провести реформування політики оплати праці. Реформа заробітної плати має охоплювати ринковий і неринковий сектори економіки та мати такі цілі: підвищення платоспроможного попиту на внутрішньому ринку і зростання інвестиційної активності; реструктуризацію валового внутрішнього продукту в частині підвищення питомої ваги заробітної плати; встановлення раціональних співвідношень між заробітною платою, підприємницьким прибутком та прибутком від власності; забезпечення раціонального співвідношення в оплаті праці працівників бюджетної та небюджетної сфер.

Основні фактори, що впливають за зміну фонду оплати праці відображено на рисунку 2.

На основі вивчення прикладних питань різносторонньої проблеми формування фонду оплати праці, обліку праці та розрахунків з персоналом у розрізі основної, додаткової заробітної плати та інших заохочувальних та компенсаційних виплат вітчизняними та зарубіжними науковцями, вважаємо за доцільне запропонувати такі напрями удосконалення класифікації виплат у розрізі фонду оплати праці для вітчизняних підприємств:

- доопрацювати та внести зміни до Кодексу законів про працю України шляхом доповнення статтею "Структура заробітної плати"в якій визначити всі елементи, що мають до неї входити враховуючи вимоги сьогодення;

- ми пропонуємо під структурою заробітної плати розуміти внутрішню будову заробітної плати, яка виступає винагородою працівникові за виконану ним працю та складається 3 логічно-впорядкованих та пов'язаних між собою елементів заробітної плати - основної (базовий фонд), додаткової (додатковий фонд), інших заохочувальних та компенсаційних виплат (заохочувальний фонд);

- націлити структуру фонду оплати праці на соціально-економічний характер відповідно до специфіки діяльності окремого підприємства та узгодження процесу формування фонду оплати праці із загальними цілями розвитку підприємства, його корпоративною та кадровою стратегіями;

- ввести нові види виплат відповідно до вимог часу, які б виражали продуктивність і ефективність праці з метою мотивування висококваліфікованих працівників та на основі індивідуальних результатів окремого працівника;
- застосувати досвід розвинених країн, де заробітна плата кожного окремого працівника формується з трьох складових фонду оплати праці (оклад+премї̈+пільги), у вигляді пільг можна урізноманітнити інші заохочувальні та компенсаційні виплати (такими пільгами можуть стати додаткове медичне страхування, надання працівникові мобільного телефону, службовий автомобіль, абонемент до спортзалу, курси англійської мови);

- застосувати досвід розвинених країн щодо регулювання системи оплати праці та пї окремих складових, ми пропонуємо в Україні зорієнтуватися на досвіді Німеччини та Великобританії, де система оплати праці побудована на стимулюванні зростання продуктивності та використанні індивідуальних контрактів, таке впровадження дасть змогу мотивувати працівників виготовляти більшу кількість та якіснішу продукцію, а в укладених індивідуальних контрактах - прописувати всі умови праці, що насамперед допоможе ефективніше захищати права найманих працівників [9];

- широко застосовувати преміальну систему оплати праці, яка дасть змогу диференціювати розміри заробітної плати залежно від індивідуальних результатів праці кожного окремого працюючого.

Важливість механізму щодо особливостей формування фонду оплати праці з точки зору забезпечення ефективності функціонування будь-якого підприємства складно переоцінити, однак, розробка напрямів удосконалення, які направлені на вирішення проблем щодо формування фонду оплати праці, обліку праці та розрахунків з персоналом у розрізі основної, додаткової заробітної плати та інших заохочувальних та компенсаційних виплат має виступити вагомим важелем щодо забезпечення стійкості та конкурентоспроможності суб'єктів господарювання, в подальшому сприятиме підвищенню ефективності як формування фонду оплати праці, так і діяльності підприємства загалом.

\section{ВИСНОВКИ ТА ПЕРСПЕКТИВИ ПОДАЛЬШИХ ДОСЛІДЖЕНЬ}

Виходячи з вищевикладеного, можна стверджувати, що на кожному підприємстві структура фонду оплати праці повинна мати соціальноекономічний характер. Аослідивши структуру фонду оплати праці в розрізі основної заробітної плати, додаткової та інших заохочувальних та компенсаційних виплат ми дійшли висновку, що Інструкція зі статистики заробітної плати дає тільки перелік виплат, які відносяться до кожного елемента фонду оплати праці та не 
грунтується на аналітичності інформації, детального її групування та не в повній мірі задовольняє потреби працівників та системи управління підприємства. Протягом останнього десятиріччя заробітна плата українських працівників формується лише з елемента основної заробітної плати, який і становить базовий фонд оплати праці на підприємстві. Аише деякі бюджетні установи і великі приватні підприємства (компанії) формують заробітну плату і ще з використанням фонду додаткової заробітної плати. Те що стосується інших заохочувальних та компенсаційних виплат то вони відсутні у заробітній платі працівників. Україна потребує радикальних змін в організації й стимулюванні ефективності праці, оптимізації диференціації доходів працівників та їх оподаткування, це має стати запорукою сталого соціально-економічного розвитку. Тому цілком важливою є потреба у своєчасній, об'єктивній і достовірній інформації щодо оплати праці з погляду кожної із сторін соціально-трудових відносин - держави, роботодавця і найманого працівника.

Подальші наші дослідження будуть спрямовані на вивчення міжна родного досвіду одного з елемента фонду оплати праці, а саме - інших заохочувальних та компенсаційних виплат, 3 метою запозичення досвіду для України.

\section{$\Lambda$ ітература:}

1. Інструкція зі статистики заробітної плати: Затверджена наказом Міністерства статистики України від 13 січня 2004 року № 5 [Електронний ресурс]. - Режим доступу: http:// www.ukrstat.gov.ua

2. Кодекс законів про працю України від 10.12.1971 р. № 322-VIII // Відомості Верховної Ради. - 1971. - № 50. - Ст. 375.

3. Конституція України від 28.06.1996 р. № 254к/96-ВР // Відомості Верховної Ради УКраїни. - 1996. - № 30. - Ст. 141.

4. Корягін М. В. Структура фонду оплати праці як основа організації бухгалтерського обліку / М. В. Корягін, О. О. Попкова // Вісник Національного університету "Аьвівська політехніка". - 2012. - № 721: Менеджмент та підприємництво в Україні: етапи становлення і проблеми розвитку. - С. 114-119.

5. Податковий кодекс України від 2 грудня 2010 року № 2755-VI [Електронний ресурс]/ Офіційний сайт Верховної Ради України. - Режим доступу: http://zakon2.rada.gov.ua/laws/ show/2755-17

6. Постанова КМУ "Про упорядкування структури та умов оплати праці працівників апарату органів виконавчӧ̈ влади, органів прокуратури, судів та інших органів" № 268 від 09.03.2006 р. [Електронний ресурс]. - Режим доступу: https://zakon.rada.gov.ua

7. Про оплату праці: Закон України від 24.03.1995 р. № 108/95-ВР // Відомості Верховної Ради України. - 1995. - № 17. - Ст. 121.

8. Яременко А.М. Концептуальні засади оплати праці в умовах ринкової економіки / М.М. Яременко // Економічний вісник університету: зб. наук. пр. Переяслав-Хмельницького держ. пед. ун-ту ім. Г. Сковороди. - 2010. № 15/1. - C. 187-190.

9. Tybinka, G. Analysis of system of Organization of Adjusting of Payment of Labor in Ukraine. Scientific enquiry in the contemporary world: theoretical basics and innovative approach. USA, San Francisco, California. - 2014. - P. 117-124.

\section{References:}

1. State Statistics Service of Ukraine (2004), "Instruction on wage statistics", available at: http:/ /www.ukrstat.gov.ua/ (Accessed 30 Dec 2019).

2. Verkhovna Rada of Ukraine (1971), "The Labor Code of Ukraine", Kodeks zakoniv pro pratsiu Ukrainy, Vidomosti Verkhovnoi Rady, vol. 50.

3. Verkhovna Rada of Ukraine (1996), "The Constitution of Ukraine", Vidomosti Verkhovnoi Rady Ukrainy, vol. 30.

4. Koriahin, M.V. and Popkova, O.O. (2012), "Structure of the payroll fund as a basis for accounting organization", Visnyk Natsional'noho universytetu "L'vivs'ka politekhnika". Menedzhment ta pidpryiemnytstvo v Ukraini: etapy stanovlennia i problemy rozvytku, vol. 721, pp. 114-119.

5. Verkhovna Rada of Ukraine (2010), "Tax Code of Ukraine", available at: http://zakon.rada.gov.ua/ laws/show/2755-17 (Accessed 25 Dec 2019).

6. Cabinet of Ministers of Ukraine (2006), Resolution "On streamlining the structure and conditions of remuneration of employees of the apparatus of executive bodies, prosecutors, courts and other bodies", available at: https://zakon.rada.gov.ua (Accessed 15 Dec 2019).

7. Verkhovna Rada of Ukraine (1995), The Law of Ukraine "On remuneration", Vidomosti Verkhovnoi Rady Ukrainy, vol. 17.

8. Yaremenko, L.M. (2010), "Conceptual principles of remuneration in a market economy", Ekonomichnyj visnyk universytetu: zb. nauk. pr. Pereiaslav-Khmel'nyts'koho derzh. ped. un-tu im. H. Skovorody, vol. 15/1, pp. 187-190.

9. Tybinka, G. (2014), Analysis of system of Organization of Adjusting of Payment of Labor in Ukraine. Scientific enquiry in the contemporary world: theoretical basics and innovative approach, San Francisco, California, USA, pp. 117-124. Стаття надійшла до редакчї 08.01.2020 p. 